\title{
PENGARUH KEMASAKAN EMOSI TERHADAP PERILAKU MENCARI OPINI PADA KONSUMEN TELEPON SELULER
}

\author{
Benny Herlena \\ Universitas ISlam Negeri Sunan Kalijaga Yogyakarta
}

\begin{abstract}
Opinion seeking behavior is defined as actively seeking information and advice about product that will be purchased. Opinion seeking behavior is influenced by some factors, e.g. personal characteristic and demography. Personal characteristic include emotional maturity. Emotional maturity is a state of individual emotion that refiect emotion stability. Demography include gender.

The purpose of this study is to understand the role of emotional maturity and gender on opinion seeking behavior of cellular phone consumers. Regression analysis was used to seek the correlation between emotional maturity and gender with opinion seeking behavior. Regression analysis, T-test and analysis of variance were employed to understand the possible difference befween male and female on their opinion seeking behavior. 274 subjects were participated in this study.

The regression analysis showed the correlation between emotional maturity and gender with opinion seeking behavior is significant with Beta $=0,549, R=0.549, R^{2}=0.301$ and $p=$ 0.000 . The analysis of variance also showed differences between male and female consumer in their opinion seking behavior with $F=211.093, R^{2}=0.437$, and $p=0.000$. From the t-test differences exist between male and female consumer in their opinion seeking behavior, with $t$ score $=14.529, F=2.561$, and $p=0.000$, mean value for male is 89.000 , and mean value for female is 69.3265 . It's indicating that opinjon seeking behavior of male consumer is higher than female consumer:
\end{abstract}

Key words: emotional maturity, gender, and opinion seeking behavior

\section{Pengantar}

Teknologi telekomunikasi yang berkembang pesat saat ini memungkinkan terjadinya peningkatan kecepatan pergerakan aktivitas manusia, dari masalah yang sederhana hingga urusan bisnis yang rumit sekalipun. Mesin faximile, serat optik dan jaringan kabel perlahan sudah mulai ditinggalkan. Jaringan nirkabel merupakan salah satu alternatif unggulan yang dapat digunakan untuk mengganti jaringan kabel maupun serat optik. Naisbitt (1997) mengemukakan bahwa untuk pemakalan individual, sejak tahurn 1995 yang silam, telepon seluier merupakan barang dagangan yang laku keras di seluruh Asia, Di Hongkong, satu dari setiap 20 orang memiliki telepon seluler. Ini merupakan tingkat pemilikan telepon seluler per kapita terbesar ketiga di dunia setel ah Jepang.

Dalam waktu yang sangat singkat, konektivitas nirkabel menjadi sebuah produk massal yang setara dengan barang-barang konsumen lainnya. Kondisi ini terus berkembang dengan sangat pesat di berbagai kota besar dunia, seperti Hongkong, Tokyo, Taipei, London, dan New York. Demikian pula halnya yang terjadi di Indonesia. Sejak telepon seluler mulai masuk ke Indonesia pada awal tahun 1995 , perkembangannya sangat cepat. Hal 
tersebut dapat diketahui dari banyaknya operator telepon seluler serta jaringan transmisi yang didirikan.

Pertumbuhan pasar seluler di Indonesia pada tahun-tahun mendatang diperkirakan oleh banyak kalangan analis pemasaran teknologi informasi dinilai sangat menjanjikan. Hal tersebut dapat diprediksi dengan terus membanjirnya produk-produk telepon seluler terbaru yang diluncurkan oleh para produsen ke pasar seluler. Hampir setiap bulan telepon seluler jenis baru muncul di pasar seluler, susul menyusul menunjukkan keunggulannya. Distributor telepon seluler senantiasa bersaing ketat mengadu strategi memasarkan produknya. Berbagai cara dilakukan agar produknya laku, dan sudah pasti semua produsen menawarkan keunggulannya.

Sebenarnya kondisi tersebut menguntungkan konsumen, minimal untuk pilihan yang semakin beragam, mulai dari desain, teknologi dan fasilitas hingga harga. Di sisi lain, di balik maraknya pasar seluler tersebut, konsumen pun semakin bingung memilih model dan merek yang harus dibeli. Konsumen telepon seluler sering tidak merasa bahwa mereka menjadi target permainan para produsen telepon seluler yang senantiasa berusaha menonjolkan keunggulan produk-produknya. Ketika menawarkan produknya, produsen cenderung menonjolkan keunggulan dan sisi baiknya saja. Mereka tidak mengungkapkan kerugian-kerugian yang dapal dialami oleh konsumen. Sebagaimana dikemukakan oleh Schiffman dan Kanuk (2000) bahwa secara umum informasi yang diberikan penjual hanya memuat hal-hal yang sifatnya positif dan menyenangkan, jarang menjelaskan sisi negatifproduknya.

Kebanyakan dari konsumen menerima informasi tentang sualu produk berasal dari iklan maupun dari pedagang yang aktif menawarkan produknya (sa/es). dan biasanya informasi yang diberikan tersebut cenderung menonjolkan keunggulannya saja, tidak menginformasikan kemungkinan sisi negatif atau kerugian yang dapat terjadi, khususnya untuk masa post-purchase. Untuk menghindari terjadinya hal tersebut konsumen dapat melakukan pencarian opini (opinion seeking) tentang produk yang akan dikonsumsinya.

Pandangan yang dikemukakan oleh para ahli tentang pengertian mencari opin (opinion seeking) secara umum tidak jauh berbeda antara salu ahli dengan yang lainnya. Wells dan Prensky (1996) mengemukakan bahwa perilaku mencari opini adalah perilaku konsumen yang mencari informasi dari orang-orang yang memiliki pengetahuan atau pengalaman tentang suatu produk. Assael (1998) mengemukakan bahwa perilaku mencart opini adalah perilaku mengumpulkan informasi dari sumber yang dianggap memiliki kredibilitas dan tidak memiliki hubungan dengan produk, seperti sales dan media iklan. Sutisna (2001) mengemukakan bahwa perilaku mencari opini merupakan perilaku konsumen dalam mencari informasi dari pemimpin opini (opinion leader) tentang produkyang akan dibelinya.

Menurut Schiffman dan Kanuk (2000) perilaku mencari opini adalah perilaku konsumen yang secara aktif mencari informasi dan saran tentang produk yang akan dikonsumsi. Lebih lanjut Schiffman dan Kanuk (2000) menjelaskan bahwa informasi yang dicari tersebut bukan saja hal-hal yang sifatnya positif dan menyenangkan (fiavorable) tetapl juga tentang sisi negatif produk (unfavorable), serta melakukan analisis kegunaan dan untung ruginya jika mengkonsumsi produk yang ditawarkan.

Dari berbagai pendapat para ahli tersebut dapat disimpulkan bahwa perilaku mencari opini dapat diartikan sebagai perilaku konsumen dalam mencari informasi dari orang-orang yang tidak memiliki hubungan dengan produk, dan memiliki pengalaman, pengetahuan, serta kredibilitas tentang suatu produk yang akan dikonsumsi, yang meliputi segi positif produk, segi negalff produk, dan analisis kegunaan serta untung ruginya jika mengkonsumsi produk yang ditawarkan.

Melalui pencarian informasi tersebut, konsumen melakukan usaha yang sungguhsungguh guna mencari informasi yang 
benar-benar akurat, khususnya yang didasari oleh pengalaman-pengalaman nyata tentang pemakaian produk yang bersangkutan. Pengalaman personal secara nyata dari konsumen lain yang pernah mengkonsumsi suatu produk akan lebih disukai daripada informasi yang berasal dari sales atau toko penjual, sebagaimana dikemukakan oleh Kotler (2000) bahwa sales maupun toko penjual merupakan salah satu ujung tombak dalam marketing yang memilikj peran penting agar produk yang ditawarkan dapat laku. Sebelum menghadapi konsumen, para sales telah dibekali berbagai strategi maupun trick unkuk menjaring konsumen.

Jika dalam proses pencarian opini tersebut seorang konsumen hanya mengandalkan informasi dari sales atau dari toko penjual, terlebih hanya dari iklan, konsumen dapat terjebak dalam perangkap para sales. Akan lebih bijaksana jika mencari informasi yang bersumber dari suatu pengalaman atau dari orang-orang yang dianggap memiliki kredibilitas dalam suatu kategori khusus, misalnya teknisi telepon seluler atau pemakai telepon seluler yang memiliki latar belakang pendidikan teknik elektro-informatika.

Hasil penelitian yang dilakukan oleh Hadipranata (1980) terhadap konsumen di Indonesia, ditemukan bahwa secara umum terdapat kecenderungan konsumen di Indonesia ketika mengkonsumsi suatu produk didasarkan pada keseragaman kelompoknya. Adanya kecenderungan pada keseragaman kelompok tersebut mencerminkan bahwa konsumen di Indonesia memiliki kecenderungan budaya konformis terhadap kelompok serta adanya kecenderungan perilaku kohesivitas yang tinggi. Kecenderungan budaya konformis yang dimiliki oleh konsumen dapat memperkecil perilakunya dalam hal pencarian opini, khususnya dari sumbersumber yang menguasai bidangnya (expert) karena cenderung mengikuti kelompoknya.

\section{DasarTeori \\ Aspek-aspek Perilaku Meneari Opini} Schiffman dan Kanuk (2000) mengemukakan bahwa perilaku mencari opini pada konsumen memiliki tiga aspek, yaitu aspek informasi, aspek kewaspadaan, dan aspek manfaat.

Aspek informasi, mengandung makna tentang bagaimana konsumen mencari informasi tentang produk yang akan dikonsumsi, yang telah masuk kedalam kategori pilihan berdasar pada hasil seleksi. Setelah konsumen mengetahui kebutuhannya dan telah selesai melakukan seleksi terhadap jenis-jenis produk yang ditawarkan, langkah berikutnya konsumen mencari informasi tentang produk-produk yang telah diseleksinya tersebut. Informasi yang dicari biasanya berasal dari sumbersumber yang layak dipercaya, seperti dari orang yang telah lebih dulu mengkonsumsi produk, dari teknisi jlka produk yang akan dikonsumsi berupa peralatan mekanis, atau dari sumber-sumber bacaan yang memberikan pertimbangan-pertimbangan negatif dan positiftentang suatu produk.

Konsumen tidak hanya mencari informasi yang bersifat umum, akan tetapi sudah menyangkut pada hal-hal yang mendetail dari suatu produk. Dalam kasus pembelian produk telepon seluler misalnya, konsumen tidak hanya mengetahui jenis telepon seluler apa yang sesuai dengan kualifikasi yang diharapkan, akan tetapi melakukan pembandingan-pembandingan untuk suatu jenis telepon seluler yang sama dari berbagai merek yang beibeda, menyangkut fasilitas menu, memori, frekuensi, SAR (Specific Absorption Rate), tegangan arus listrik, jenis baterai, kesesuaian untuk peningkatan perangkat lunaknya, kekurangan yang mungkin ada, dan sebagainya,

Aspek kewaspadaan, mengandung makna tentang bagaimana konsumen bersikap selalu waspada, khususnya berkaitan dengan masalah segi negatif produk atau berusaha meminimalkan resiko menanggung kerugian yang kemungkinan akan dialami. Selain itu aspek kewaspadaan juga mengandung makna tentang bagaimana konsumen senantiasa bersikap selalu waspada dari bujuk rayu penjua! produk, sehingga konsumen senantiasa 
tetap mengingat saran-saran dari pemberi opini (opinion leader), dan tidak melakukan pembelian secara tergesaugesa, terlebih melakukan pembelian secara tidak rasional.

Kewaspadaan sangat diperlukan dalam suatu proses konsumsi agar di kemudian hari konsumen tidak mengalami kerugian. Dalam kasus pembelian telepon seluler misalnya, seorang konsumen harus berhati-hati, berperilaku cermat dan teliti dalam melakukan pemilihan jenis telepon seluler yang akan dikonsumsinya. la tidak memilih sejenis telepon seluler hanya karena tergiur iklan telepon seluler yang menarik dan sering menawarkan berbagai keunggulan, atau terpengaruh bujuk rayu salos di toko telepon seluler yang belum tentu sales itu sendiri telah lama berpengalaman menggunakan jenis telepon seluler yang ditawarkannya.

Kewaspadaan lebih diperlukan lagi terutama bila ada penawaran telepon seluler yang tidak bergaransi yang lebih dikenal dengan istilah telepon seluler BM (black market), maupun telepon seluler ref stbish. Konsumen juga harus memperhatikan kerugian-kerugian yang kemungkinan akan dialaminya bila ia membeli suatu jenis telepon seluler. Untuk menghindari hal ini, usaha yang baik untuk diterapkan adalah konsumen rajin mencari informasi-informasi yang bersifat product review maupun Informasi dari orang-orang yang memang memiliki kredibilitas yang tinggi di bidang telepon seluler, seperti para teknisi telepon seluler, peneliti ilmiah di bidang elektroinformatika maupun pengalamanpengalaman negatif dari orang-orang yang pernah memakai sejenis teiepon sefuler. Informasi-informasi yang berasal dari sumber-sumber tersebut pada umumnya berisikan perbandingan-pebandingan dari berbagai jenis telepon seluler yang secara umum berisi informasi tentang kerugiankeruglan yang dapat dialami di kemudian hari.

Konsumen juga harus mewaspada barang-barang yang bersifat tidak lulus uj kualitas. Dalam kasus telepon seluler yang secara faktual sering dan banyak terjadi adalah dijualnya telepon seluler yang masuk ke Indonesia tidak melalui uji kelayakan, seperti jenis telepon sefuler BM yang tidak memiliki garansi resmi vendor atau dari produsen. Nilawati, Kasubdit Penerapan Postel pada Direktorat Jenderal Pos dan Telekomunikasi Indonesia, mengemukakan bahwa telepon seluler yang dipasarkan d Indonesia harus melewati laboratorium pengujian milik Direktorat Jenderal Pos dan Telekomunikasi. Tujuannya adalah untuk melindungi konsumen. Sementara telepon sefuler BM, masuk ke Indonesia tanpa melalui proses uji kelayakan, wajar saja jika sering menuai masalah. Uj kelayakan telepon seluler tersebut diatur dalam surat keputusan Direktorat Jenderal Standarisasi Pos dan Telekomunikasi. Adapun tempat pengujian atau balai uj kelayakan yang ada d Indonesia terdapat d dua tempat, yaitu pertama, di Laboratorium Pos dan Telekomunikasi Indonesia, dan kedua, di Laboratorium Riset dan Teknologi Indonesia. Kedua tempat itulah yang memlliki wewenang untuk merekomendasikan boleh atau tidaknya semua perangkat telekomunikasi beredar di masyarakat Indonesia (T \&t, Maret2002).

Contoh tentang diperlukannya kewaspadaan bagi para konsumsn telepon seluler ketika akan mengkonsumsi telepon seluler adalah waspada terhadap jenis-jenis telepon seluter refurbish yang ditawarkan sebagai telepon seluler yang masih baru (new), padahal sebenarnya adalah telepon seluler bekas (second). Berdasarkan penampilan sekilas memang tampak baru serta masih terdapat plastik stiker maupun segelnya sebagai pelindung pesawat telepon. Hal tersebut mudah saja dilakukan dengan cara mengganti casing pesawat telepon seluler tersebut dengan casing yang baru. Dalam kasus ini yang dilakukan oleh penjual adalah mengambil mainboard pesawat telepon seluler yang bekas tersebut, kemudian diberi casing baru, plastik pelindung baru, segel baru, kotak pembungkus yang baru, dan dijual dengan harga yang sama dengan harga pesawat telepon seluler baru. Antisipasl penipuan dengan modus tersebut kiranya konsumen perlu berperilaku waspada, hal ini dapat dilakukan dengan cara melakukan pengecekan pada phone code number di 
dalam menu security. Jika nomor standar pabrik yang dimasukkan tersebut diterima (accepted) hal tersebut menandakan pesawat telepon baru pertama kali dipergunakan. Sedangkan bila nomor yang dimasukkan tersebut ditolak (wrong number), maka pesawat telepon seiuler tersebut pernah dipergunakan (second). Masih banyak cara-cara lain yang dapat dilakukan untuk menlngkatkan kewaspadaan dalam mengkonsumsi telepon seluler.

Aspek manfaat, mengandung makna tentang bagaimana konsumen senantiasa memperhitungkan secara masak kriterla manfaat produk yang akan dikonsumsinya agar jangan sampai terjadi pembelian produk yang tidak membawa manfaat (useless purchase), terlebih jika hanya membuangbuang uang untuk suatu produk yang kadar kemanfaatannya sangat kecil. Dalam hal ini konsumen dituntut untuk pandai dalam memilih, karena belanja bukan hanya sekedar membeli sesuatu, tetapi merupakan suatu proses yang seharusnya direncanakan. Konsumen tidak boleh merasa bahwa ia memiliki uang yang melimpah, sehingga semua yang terlihat menarik dibelinya dengan mengabaikan manfaat dari produk yang dikonsumsi.

Konsumen telepon seluler yang berperilaku mencari opini tinggi akan memprioritaskan membeli telepon seluler yang memang sesual kebutuhannya. Yang terpentling dalam hal ini adalah manfaat atau fungsinya, bukan model atau harganya. Banyak konsumen berganti-ganti membeli telepon selular hanya sekedar yang la inginkan, padahal belum tentu barang terse but ia butuhkan.

Perilaku waspada tampaknya harus semakin ditingkatkan oleh konsumen telepon seluler, karena saat ini masih ada vendor telepon seluler mempromosikan teknologi yang belum tentu sesuai (compatible) dengan teknologi yang dimiliki oleh para operator telepon seluler, bahkan bila sudah bisa digunakan pun masih sering mengalami hambatan maupun gangguan pemakaian yang berakibat pada tidak maksimalnya pemakaian produk tersebut. Dilakukannya promosl gencar tentang teknologi yang bagi masyarakat awam tampak sebagai sesuatu yang unggul, semakin mempermudah sales di toko telepon seluler untuk membujuk konsumen agar membeli produk-produk yang diunggulkan tersebut.

Perilaku mencari opini yang dimiliki oleh konsumen tergantung pada banyak faktor. Schiffman dan Kanuk (2000) mengemukakan faktor-faktor yang dapat mempengaruhi perilaku mencari opini, antara lain karakteristik kepribadian dan demografi. Lebih lanjut menurut Schiffman dan Kanuk (2000), faktor demografi yang dapat mempengaruhi perilaku konsumen dalam proses mengkonsumsi produk antara lain jenis kelamin.

Menurut Wallendorf dan Zaltman (1984), faktor kepribadian memiliki peran terhadap perilaku konsumen. Kepribadian yang dimiliki konsumen tidak bisa begitu saja diabaikan daiam hal perilaku konsumsl. Nakanishi (Wallendorf dan Zaltman, 1984) mengemukakan bahwa kepribadian merupakan suatu konsep dinamis pada difi seseorang yang memberikan pengaruh besar terhadap perilakunya. Salah satunya adalah perilaku konsumsi yang dapat dilihat dalam proses konsumsi.

Pencarian opini yang dilakukan konsumen tentu saja tidak tertepas dari pengaruh kepribadian yang dimilikinya. Schiffman dan Kanuk (2000) menjelaskan bahwa kepribadian merupakan salah satu faktor yang dapat mempengaruhi perilaku mencari opini pada konsumen. Setiap orang mempunyai karakteristik kepribadian yang berbeda yang rnempengaruhi perilaku konsumsinya, Karakteristik kepribadian yang dimiliki oleh konsumen tersebut berpengaruh terhadap perilaku mencari opininya. Kotler (2000) mengernukakan bahwa dalam perilaku konsumsinya konsumen tidak pernah terlepas dari kepribadiannya, variabel kepribadian yang berpengaruh tersebut antara laln adalah kemasakan emosi.

\section{Kemasakan Emosi}

Morgan (1986) mengemukakan bahwa kemasakan emosi merupakan keadaan emosi yang dimiliki seseorang di mana bila mendapat stimulus emosi tidak 
menunjukkan gangguan kondisi emosi. Gangguan kondisi emosi yang terjadi tersebut dapat berupa keadaan kebingungan, berkurangnya rasa percaya diri, dan terganggunya kesadaran sehingga orang tersebut tidak dapat menggunakan pernikirannya secara efektif dan rasional.

Allport (1961) berpendapat bahwa kepribadian yang matang memiliki karakteristik emosi yang masak pula. Hal tersebut ditandai dengan dimilikinya kemampuan untuk merasakan kehangatan dalam melakukan hubungan interpersonal, mempunyai rasa arnan secara emosional, dalam arti toleran terhadap frustrasi yang dihadapi, serta dalam kondisi rasa percaya terhadap diri sendiri maupun orang lain.

Menurut Hurlock (1974) kemasakan emosi memilikl beberapa kriteria. Pertama, kontrol emosi yang secara sosial dapat diterima. Seseorang yang secara emosional dikatakan matang jika la dapat mengontrol ekspresi emosinya dengan cara-cara yang dapat diterima oleh lingkungan. Kedua, pemahaman diri. Seseorang yang secara emosional dikatakan matang jika ia mampu untuk belajar guna mengetahui berapa besar kontrol yang diperlukan untuk memuaskan kebutuhannya. Ketiga, penggunaan fungsi kritis mental. Seseorang yang secara emosional dikatakan masak jika ia mampu menilai suatu situasi secara kritis sebelum memberikan responnya secara emosional. Kemudian ia tahu secara tepat tentang bagaimana cara yang tepat untuk bereaksi terhadap situasi tersebut.

Johns dikk (1962) mengemukakan bahwa seseorang yang merniliki emosi yang belum masak dapat merugikan dirinya sendiri, karena pada kondisi emosi yang belum masak tersebut seseorang mudah mengalami hal-hal yang mengganggu kondisi psikisnya, seperti timbulnya perasaan cemas bahkan takut, mudah terstimulasi oleh respon emosi yang berasal dari orang lain, berkurangnya rasa kepercayaan pada diri sendiri, lemah pendiriannya serta mudah dipengaruhi oleh orang lain, cenderung mengabaikan pemikiran jangka panjang dan memiliki kecenderungan berpikir tidak rasional.

Hurlock (1974) mengemukakan bahwa kemasakan emosi yang dimiliki seseorang dapat ditandai dengan adanya perilaku menilai sesuatu secara kritis terlebih dahulu sebelum bereaksi secara emosional. Emosi yang masak memberikan reaksi emosional yang stabil, tidak berubah-ubah dari satu suasana hati ke suasana hati yang lain. Ditambahkan oleh Hurlock (1980) bahwa untuk mencapai kemasakan emosi, seseorang harus belajar memperoleh gambaran tentang situasi-situasi yang dapat menimbulkan reaksi emosinya. Melakukan sharing atau saling berbagi rasa dengan orang lain maupun melakukan aktivitas katarsis emosi untuk menyalurkan emosinya, misalnya melakukan kegiatan latihan fisik maupun melakukan aktivitas sosial dengan lingkungannya.

Kemasakan emosi yang dimiliki seseorang ditandai dengan adanya ciri-ciri yang dapat terihat. Adapun ciri-ciri tersebut yaitu, pertama, adanya organisasi dari sernua aspek emosi yang ada, sehingga seseorang mampu mengendalikan segala bentuk emosinya, baik emosi yang bersifat positif maupun emost yang bersifat negatif. Kedua, orang tersebut dapat menyatakan emosinya secara tepat dan wajar (Hurlock. 1980). Seseorang yang secara umum memiliki kemasakan emosi yang tinggi akan memiliki perilaku-perilaku yang bersifat positif, seperti tidak mudah mengalami kebingungan, rasa percaya diri yang tidak mudah berkurang. senantiasa dapat menggunakan nalamya secara efektif dan rasional, mampu untuk belajar dalam situasi yang sulit, menerima kritik secara lapang dada, berpikiran jangka panjang, tidak mudah cemas atau takut, tidak mudah terpengaruh (teguh pendirian), tidak obsesif maupun tidak kompulsif, senantiasa cermat dan teliti, tidak tergesa-gesa, bersikap realistis, dan tidak Infantil. Sedangkan seseorang yang secara umum memiliki kemasakan emosi yang rendah akan memiliki perilaku-perilaku yang bersifat negatif, seperti mudah mengalami kebingungan, rasa percaya diri yang tidak stabil (mudah berkurang), cenderung tidak dapat menggunakan nalamya secara efektif, cenderung berpikir tidak rasional, kurang mampu untuk belajardalam situasi yang sulit, 
tidak bisa menerima kritikan, cenderung berpikir jangka pendek, mudah cemas atau takut, mudah terpengaruh (tidak teguh pendirian), cenderung obsesif ataupun kompulsif, cenderung tidak cermat dan tidak teliti, cenderung tergesa-gesa, tidak realistis, dan cenderung infantil.

Berdasarkan berbagai pendapat tersebut dapal disimpulkan bahwa kemasakan emosi adalah suatu keadaan emosi yang dimiliki seseorang yang apabila mendapat stimulus emosi tidak menunjukkan gangguan kondisi emosi. Gangguan kondisi emosi yang terjadi tersebut dapat berupa keadaan kebingungan, berkurangnya rasa percaya diri, dan terganggunya kesadaran sehingga tidak dapat menggunakan pemikirannya secara rasional dan efektif.

Menurut Hurlock (1979) kemasakan emosi seseorang memiliki aspek-aspek sebagai suatu bentuk ciri sif at atau perilaku yang dapat terlihat (observable). Aspekaspek kemasakan emosi tersebut meliputi aspek stabilitas emosi, aspek pengendalian, aspek identifikasl, aspek intimasi, aspek minat danaspekcinta.

Aspek stabilitas emosi, merupakan cerminan dari karakteristik emosi yang masak, antara lain ditandai dengan tidak adanya perubahan emosi yang berlangsung secara cepat dan tidak menentu, adanya kepercayaan diri, serta rasa optimis dan realistis.

Aspek Identifikasi. Seseorang yang memiliki emosi yang masak dapat melakukan identifikasi emosi yang dialaminya, mampu mengekspresikannya secara tepat dan wajar, dan dapat diterima secara sosial.

Aspek pengendalian, mengungkap bagaimana cara seseorang mengendalikan emosinya. Pola kontrol inilah yang membedakan seseorang yang memiliki kemasakan emosi dengan indivldu yang belum masak, yang pada umumnya bersifat reg res if dan infantil.

Aspek intimasi, ditandai dengan keberadaan seseorang yang tidak mengalami keadaan nervous, grogi dan merasa kesulitan ketika memulai suatu perkenalan dalam bergaul.

Aspek Minat, ditandal dengan sikap realistis terhadap harapan dan aspirasi. Seseorang yang belum masak secara emosi ditandai dengan adanya sifat obsesif, sifat kompulsif, dan sifat variatif dalam hal minat yang dimilikinya.

Aspek cinta, berkaitan dengan keadaan seseorang dalam hal kepemilikan sesuatu yang sukai dan dicintainya. Seseorang yang belum masak secara emosi ditandai dengan perilaku kepemilikan dan menyukai sesuatu dengan bersifat kekanakkanakan.

Atas dasar uraian yang telah dikemukakan tersebut, kemasakan emosi yang dimiliki seseorang dalam penelitian ini meliputi enam aspek kemasakan emosi, yaitu aspek stabilitas emosi, aspek pengendalian, aspek identifikasi, aspek intimasi, aspek minat dan aspek cinta.

Proses pencapaian kemasakan emosi yang dimiliki seseorang dipengaruhi oleh banyak faktor. Beberapa peneitit dalam bidang psikologi mengemukakan bahwa faktor-faktor yang mempengaruhi kemasakan emosi seseorang antara lain adalah faktor fisik, faktor jenis kelamin, faktor intelegensi, dan faktor usia.

\section{Kemasakan Emosi dan Perilaku Mencari Opinl}

Kemasakan emosi merupakan suatu kondisi emosi yang dimiliki seseorang yang apabila mendapat stimulus emosi tidak menunjukkan adanya gangguan emosi. Gangguan emosi yang terjadi tersebut dapat berupa keadaan kebingungan, berkurangnya rasa percaya diri, dan terganggunya kesadaran sehingga orang tersebut tidak dapat menggunakan pemikirannya secara efektif dan rasional.

Menurut Schiffman dan Kanuk (2000), emosi yang dimiliki konsumen akan berpengaruh terhadap pemikiran dan perilakunya. Emosi memainkan peranan yang signifikan dalam proses konsumsi, mulai dari pengumpulan informasi, evaluasl, seleksi produk, dan pengambilan kepukusan. Bila kemasakan emosi konsumen tinggi maka konsumen memiliki perilaku mencari opini yang tinggi. Konsumen akan berhatihati dalam menyaring informasi, tidak tergesa-gesa, bersikap waspada, dan 
senantiasa teguh dalam pengambilan keputusan. Konsumen tidak mudah terpengaruh oleh bujuk rayu penjual produk. Bila kemasakan emosi konsumen rendah maka ia memiliki perilaku mencari opini yang rendah. Konsumen berperilaku tergesagesa, kompulsif, kurang waspada, dan mudah terpengaruh oleh bujuk rayu penjual produk, terlebih ketika ada tawaran produk yang diiming-imingi pemberian hadlah.

Seseorang memiliki kondisi emosi yang tidak stabil, maka hal tersebut ten tu saja akan sangat merugikan dirinya, khususnya ketika mengkonsumsi suatu produk. Bila kondisi emosi seseorang mengalami gangguan saat sedang dalam proses mengkonsumsi produk, ia akan cenderung berpikir kurang rasional, berperilaku tergesagesa, tidak cermat dan tidak teliti, kepercayaan diri berkurang, tidak punya pendirian, mudah terpengaruh, dan kontrol dirinya menjadi lemah. Hadipranata (1980) menjelaskan bahwa kestabilan emosi sangat diperlukan bagi ketenangan diri seseorang dalam bertindak.

Lebih lanjut Schiffman dan Kanuk (2000) juga mengemukakan bahwa kondisi emosi yang tidak stabil dapat muncul dalam proses konsumsi, terlebih jika produk yang ada sudah lama diinginkan oleh konsumen tersebut. Kondisi emosi konsumen dapat terpengaruh oleh suatu stimulus, sehingga respon konsumen cenderung meningkat terhadap objek yang ditujunya. Konsumen yang menentukan pilihannya dengan tanpa banyak bertanya ke sumber-sumber yang dapat dipercaya, dapat dikatakan konsumen tersebut melakukan suatu perilaku konsumsi yang tidak rasional.

Berdasar uraian di atas dapat disimpulkan bahwa seseorang yang memiliki kemasakan emosi yang tinggi cenderung memiliki perilaku mencari opini yang termasuk dalam kategori tinggi pula, karena dalam proses konsumsi ia akan senantiasa bersikap tidak tergesa-gesa baik dalam menyaring informasi yang diperoleh maupun dalam memilih suatu produk. Dalam proses konsumsi produk, akan mencari referensireferensi atau opini-opini secara sabar dan teliti, khususnya referensi yang kredibilitasnya diakui, tidak asal-asalan karena tergesa-gesa. Mereka memiliki kecenderungan memburu opini secara cermat dan teliti, seperti kepada sumbersumber yang layak dipercaya, misal dari para teknisi bila menyangkut produk mesin, bukan dari para sales yang punya kecenderungan agarproduknya laku.

Jenis Kelamin dan Perilaku Mencari Opini Pembedaan jenis kelamin konsumen sengaja diberikan karena masing-masing jenis kelamin memiliki karakteristik yang berbeda satu dengan lainnya. Menurut Solomon (1996) jenis kelamin konsumen merupakan komponen penting yang harus diperhatikan dalam proses konsumsi, karena adanya perbedaan jenis kelamin konsumen dapat memberikan kejelasan untuk membuat segmentasi (segmentation) di pasar, baik untuk segmentasi produk maupun segmentasi strategi menyiasati karakteristik konsumen. Strategi yang biasa diterapkan guna menyiasati karakteristik konsumen adalah pengolahan segmentasi yang didasarkan pada kondisl emosional konsumen, karena laki-laki dan perempuan memiliki perbedaan emosi.

Kondisi emosi yang berbeda antara laki-laki dan perempuan digunakan sebagai strategi untuk menarik konsumen. Adanya perbedaan emosi antara laki-laki dan perempuan tersebut, secara langsung akan mempengaruhi pula perilaku seseorang dalam proses konsumsi yang mereka lakukan. Konsumen yang cenderung emosional kurang berhati-hati dalam menyaring informasi, tidak waspada, dan cenderung tergesa-gesa sehingga lemah dalam hal pencarian opini. Selain itu konsumen mudah goyah serta terpengaruh dalam hal pengambilan keputusan untuk membeli sehingga cenderung akan mudah terbujuk oleh rayuan penjual produk (Schiffman dan Kanuk, 2000).

Mengenai perbedaan emosi antara laki-laki dan perempuan tersebut dapat dilakukan tinjauan pada hasil penelitian yang dilakukan oleh Hasanat (1994) tentang perbedaan emosi antara laki-iaki dan perempuan. Melalui hasil penelitian ditemukan bahwa secara umum perempuan lebih emosional bila dibandingkan dengan 
laki-laki. Hasil studi yang dilakukan oleh Brislin (1993) juga menemukan bahwa perempuan memiliki tingkatemosi yang lebih tinggi dalam berbagai jenis emosi dibandingkan laki-laki.

Demikian pula halnya dengan adanya anggapan yang dimiliki oleh produsen, bahwa perempuan cenderung memiliki tradisi konsumtif yang tinggi dibandingkan dengan laki-lakt. Perempuan lebih senang dan banyak berkunjung ke tempat-tempat perbelanjaan bila mereka memiliki waktu luang. Mereka juga berbelanja mulai dari keperluan sehari-hari seperti sembako hingga barang-barang untuk kecantikan maupun asesoris. Perempuan sering dijadikan objek dalam penawaran barang oleh produsen. Hal ini dapat dilthat dari media massa yang banyak menayangkan iklan dengan segmentasi kaum perempuan. Selain karena perempuan memegang peranan dalam urusan pengelolaan rumah tangga, juga aspek psikologis yang mereka miliki, menyangkut kondisi emosi mereka yang cenderung mudah dipengaruhi dan dibujuk untuk membeli (Abrar, dalam Ibrahim dan Suranto, 1998).

Berkaitan dengan kondisi perempuan yang cenderung emosional ketika melakukan proses mengkonsumsi produk, dapat dikatakan bahwa kondisi perempuan yang cenderung emosional mengakibatkan perilaku kurang berhati-hati dalam menyaring informasi. Kecenderungan emosional akan mengakibatkan perilaku tidak waspada, mudah goyah dan mudah terpengaruh dalam hal pengambilan keputusan untuk membeli, sehingga mudah terbujuk oleh penjual produk. Kecenderung tergesa-gesa sebagal akibat dari keadaan dirinya yang emosional akan mengakibatkan banyaknya informasi yang terlewatkan, sehingga dapat dikatakan tejadi kelemahan dalam perilaku mencari opininya.

Kesimpulan yang dapat diambil adalah perempuan cenderung kurang dibandingkan dengan laki-laki dalam hal pencarian opini, karena perempuan memiliki kecenderungan sifat emosional yang dapat membawa kepada sikap dan perilaku mudah dibujuk dan dirayu, serta cendenung tergesagesa untuk segera memiliki produk yang diinginkannya. Terlebih bila produknya sesual dengan keinginannya dan sangat terbatas kuantitas produknya.

\section{Hipotesis}

1. Kemasakan Emosi memiliki hubungan positif dengan perilaku mencari opini konsumen. Semakin tinggi tingkat kemasakan emosi konsumen semakin tinggi pula perilaku mencari opini konsumen.

2. Terdapat perbedaan perilaku mencari opini didasarkan pada perbedaan jenis kelamin konsumen. Konsumen laki-laki memiliki perilaku mencari opini yang lebih tinggi dibandingkan konsumen perempuan.

\section{Metode Penelitian}

Subjek dalam penelitian ini adalah konsumen telepon seluler di Yogyakarta, dengan beberapa karakteristik yang telah disesuaikan dengan tujuan penelitian. Jumlah subjek yang terkumpul dalam penelitian ini adalah 274 subjek, terdiri dari 127 subjek laki-laki dan 147 subjek perempuan.

Skala perilaku mencari opini disusun berdasarkan teori yang dikemukakan oleh Schiffman dan Kanuk (2000). Butir-butir pernyataan dalam skala perilaku mencari opini mencerminkan aspek-aspek perilaku mencari opini yang terdiri dari tiga aspek, yaitu aspek informasi, aspek kewaspadaan, dan aspek manfaat. Skala ini disusun oleh peneliti sebanyak 28 butir pemyataan. Hesil uji validitas setiap aitem pada skala perilaku mencari opini diperoleh koefisien korelași yang bergerak dari $0,328 \quad 0,727$, dan hasil uji reliabilites skala perilaku mencari opini diperoleh alpha sebesar $=0,9518$.

Skala kemasakan emosi disusun berdasarkan teori yang dikemukakan oleh Hurlock (1979), yang terdiri dari enam aspek kemasakan emosi, yaitu aspek stabilitas emosi, aspek identifikasi, aspek pengendalian, aspek intimasi, aspek minat, dan aspek cinta. Skala inf disusun oleh peneliti sebanyak 32 butir pernyataan. Hasil uji validitas setiap aitem pada skala 
kemasakan emosi diperoleh koefisien korelasi yang bergerakdari $0,630 \quad 0,976$, dan hasil uj̄ reliabilitas skala kemasakan emosi diperoleh alpha sebesar $=0,9133$.

Model analisis statistik yang digunakan untuk mengetahui pengaruh kemasakan emosi terhadap perilaku mencari opini konsumen digunakan analisis regresi. Modei analisis statistik yang digunakan untuk mengetahui perbedaan tingkat perilaku mencari opini konsumen antara konsumen laki-laki dan konsumen perempuan digunakan analisis variansi maupun uji t

\section{Hasil Penelitian}

Berdasar hasil uij regresi yang telah dilakukan, diperoleh nilai Beta $=0,549, R=$ $0,549, R^{2}=0,301$ dengan $p=0.000$. Hal ini menunjukkan bahwa terdapat korelasi positif yang signifikan antara kemasakan emosi dan jenis kelamin dengan perilaku mencari opini, sehingga hipotesis penelitian yang berbunyi kemasakan emosi dan jenis kelamin memiliki hubungan dengan perilaku mencart opini konsumen dapat diterima.

Hasil uji analisis variansi untuk mengetahui perbedaan perilaku mencari opini didasarkan pada pengaruh variabel jenis kelamin, diperoleh $F=211,093, R^{2}=$ 0,437 , dengan $p=0,000$. Berdasar hasil uji $t$ diperoleh nilai $t=14,529, F=2,561$, dengan $p=0,000$, nilai mean laki-laki $=89,0000$ dan nilai mean perempuan $=69,3265$ menunjukkan bahwa terdapat perbedaan yang signifikan dalam hal perilaku mencari opini ditinjau dari jenis kelamin konsumen.

\section{Pembahasan}

Hasil analisis regresi antara kemasakan emosi dengan perilaku mencari opini menunjukkan bahwa kemasakan emosi berperan terhadap perilaku mencari opini konsumen. Hal ini membuktikan bahwa kemasakan emosi yang dimiliki oleh konsumen berperan terhadap perilakunya dalam proses konsumsi (Schiffman dan Kanuk, 2000).

Konsumen yang masak secara emosi cenderung memiliki pengendalian diri, sehingga dalam proses konsumsi ia senantiasa dapat mengontrol dorongandorongan yang timbul untuk melakukan pembelian secara tidak rasional (Engel dkk, 1995). Konsumen yang memiliki kontrol diri akan cenderung dapat mengontrol perilakunya untuk mengkonsumsi produk sehingga dalam proses konsumsi senantiasa tidakberlebihan (Lina dan Rosyid, 1997).

Konsumen secara umum memiliki kecenderungan tergesa-gesa dalam melakukan pembelian, khususnya bagi mereka yang secara ekonomi mampu menjangkau harga yang ditetapkan, serta produk yang ditawarkan sudah bersifat umum bagi lingkungannya, sehingga konsumen sangat jarang melakukan penggalian informasi terhadap produk yang identik atau produk sejenis yang ditawarkan (Engel, 1995).

Konsumen yang melakukan pernbelian secara emosional cenderung mengabaikan detail-detail informasi mengenai produk yang akan dikonsumsinya. Marketeryang piawai dalam memainkan dan memberikan sentuhan emosional kepada konsumen akan dengan mudah mempengaruhi konsumen untuk mengkonsumsi produk yang ditawarkannya (Kotler, 2000).

Analisis deskriptif penelitian ini juga menunjukkan bahwa tingkat perilaku mencari opini yang dimiliki oleh subjek penelitian, dalam hal ini konsumen telepon seluler, termasuk dalam kategori tidak cukup tinggi (kategori sedang). Hal ini diprediksi sebagai akibat dari adanya pengaruh variabel lain yang dimiliki oleh konsumen telepon seluler yang menjadi subjek peneltian hi. Peneliti menduga bahwa variabel lain tersebut adalah varlabel budaya. Hal ini didasarkan pada temuan hasil penelitian Hadipranata (1980).

Menurut Hadipranata (1980). berdasar hasil penelitiannya terhadap konsumen di Indonesia, dikemukakan bahwa secara umum terdapat kecenderungan konsumen di Indonesia daiam mengkonsumsi suatu produk didasarkan pada keseragaman kelompoknya. Adanya kécenderungan pada keseragaman 
kelompok tersebut mencerminkan bahwa konsumen di Indonesia memiliki kecenderungan budaya konformis terhadap kelompok serta adanya kecenderungan perilaku kohesivitas yang tinggi. Hal senada juga dikemuakan oleh Engel (1995), bahwa kecenderungan seseorang untuk bergabung pada kelompoknya mempengaruhi pemillhan terhadap produk yang dikonsumsinya.

Kecenderungan budaya konformis inilah yang diduga kuat sebagal penyebab tidak cukup tingginya perilaku mencari opini konsumen telepon seluler. Kecenderungan budaya konformis yang dimiliki oleh konsumen dapat memperkecil perilakunya dalam hal pencarian opini, khususnya terkait opini yang berasal dari sumber-sumber yang menguasai bldangnya (expert).

Selanjutnya hasil penelitlan ini juga menunjukkan adanya perbedaan tingkat perilaku mencari oplni berdasarkan pada kategorisasi jenis kelamin. Konsumen lakilaki memiliki perilaku mencari opini yang lebih tinggi dibandingkan dengan konsumen perempuan. Penemuan ini sejaian dengan pendapat yang dikemukakan oleh Schiffman dan Kanuk (2000) bahwa perbedaan jenis kelamin yang dimiliki oleh konsumen membuktikan pula adanya perbedaan dalam hal perilaku mencari opinl.

Berdasar hasll penelitian Ini ditemukan pula bahwa konsumen laki-laki cenderung tertarik pada hal-hal yang sifatnya teknologi, yaltu software handphone. Pada konsumen perempuan cenderung tertarik pada style atau model telepon seluler secara fisik.

\section{Kesimpulan dan Saran}

Kemasakan emosi berperan secara sangat slgnifikan terhadap perilaku mencari opini konsumen. Berdasarkan pada kemasakan emosi yang dlmilikinya, seorang konsumen akan dapat mengendalikan perilakunya dalam mengkonsumsi produk, tidak tergesa-gesa dan tidak mudah terpengaruh oleh bujukan-bujukan yang dapat merugikan dirinya dalam melakukan konsumsi produk.

Tidak cukup tingginya perilaku mencarl opini yang pada konsumen subjek penelitian ini diprediksi terkait dengan pengaruh budaya yang dimiliki, perlu untuk diteliti lebih lanjut dan mendalam, terutama tentang budaya konformis dikaitkan dengan perilaku mencari opini konsumen. Sehingga bisa menambah pemahaman tentang perilaku mencari opini pada konsumen.

Selain itu agar dilakukan pula kontrol terhadap variabel demografi yang lain, misal pekerjaan, besarnya penghasilan, status sosial, dan lain-lain, yang mungkin akan berpengaruh terhadap perilaku mencari opini konsumen.

\section{Daftar Pustaka}

Allport, G.W. 1961. The Individual and His Religion: A Psychological interpretation. New York : The McMillan $\mathrm{Co}$

Assael, H. 1998. Consumer Behavior and Marketing Action. Cincinnati, Ohio : South Western College Publishing.

Brislin, R. 1993. Understanding Culture's Influence on Behavior. OHando: Harcourt Brace College Publisher.

Engel, J.F., Kollet, D.T, \& Blackwell, R.D. 1995. Consumer Behavior. Sixth Edition. New York : The Dryden Press.

Hadipranata, A.F. 1980. Peranan Kelompok Tidak Resmi Terhadap Tingkah Laku Memilih Dan Membeli Barang Baru. Laporan Hasil Penelitian (tidak diterbitkan). Yogyakarta: Fakultas Psikologi UGM.

Hasanat, N. 1994. Apakah Perempuan Leblh Depresif Daripada Lakl-kaki? Laporan Penelitian (tidak diterbitkan). Yogyakarta : Fakultas Psikologi Universitas Gadjah Mada.

Hurlock, E.B. 1974. Personality Development. New Delhi : McGraw Hill. 
1979. Adolescent Development. New York: McGraw Hill

1980. Development Psychology: A Lfe Span Approach. New York : McGraw Hill.

Ibrahim, I.S. dan Suranto H. 1998. Wanita dan Media. Bandung : Penerbit Remaja Rosdakarya.

Johns, E.B. 1962. Health For Effective Living. New York: McGraw-Hill Co.

Kotler, P. 2000. Marketing Management. New Jersey: Prentice-Hall, Inc.

Lina., dan Rasyid, H.F. 1997. Religiusitas dan Sikap Konsumtif Pada Wanita. Jurnal Psikologika. Yogyakarta Universitas Islam Indonesia.

Lone, P. \& Shrene,A. 1986. Working Woman : A Gudo to Filness and Health. Toronto : The Mosby Co.

Moloney, K.P. 2001. Multi-Skills, Emotional Component, Restructuring Organization and Bullying Behaviour At Work. Europlan Journal of Marketing. Vol20.1/2.

Morgan, C.T. 1986. Infroduction to Psychology. New York : McGraw-Hill, Co.
Naisbitt, J.1997. Megatrends Asla. Jakarta: PT Gramedia.

Powell, M. 1963. The Psychology of Adolescence. New York: The BobbsMeril, Co.

Schiffman, L.G. dan Kanuk, L.L. 2000. Consumer Behavior. Singapore : Prentice- Hall Intemational Inc.

Solomon, M.R. 1996. Consumer Behavior: Buying, Having, and Being. New Jersey: Prentice Hall.

Sutisna. 2001. Perilaku Konsumen dan Komunikasi Pemasaran. Bandung: Penerbit Rosdakarya.

T\&t 2002. Ponsel BM di Pasaran. Majalah T\&1 Mobile Lifostyle. Edisi 03/ll Maret 2002.

Wallendorf, M. dan Zaltman, G 1984. Readings in Consumer Behavior. Canada : John Wiley 8 Sons, hnc.

Wells, W.D. \& Prensky, D. 1996. Consumer Behavior. New York : John Wiley \& Sons, Inc. 